\title{
A Problemática do marco inicial da Personalidade Jurídica no Paradigma da Pessoalidade e da Dignidade Humana
}

\author{
The problematics of the initial framework of Legal Personality in \\ the Paradigm of Personality and Human Dignity
}

\author{
Antonio Marinho de Melo Rodrigues Filho ${ }^{1}$
}

Victor Sales Pinheiro ${ }^{2}$

\begin{abstract}
RESUMO
O presente artigo busca analisar a problemática referente ao marco inicial da personalidade jurídica da pessoa natural. $\mathrm{O}$ ordenamento jurídico brasileiro não apresenta de forma clara um entendimento referente ao momento no qual o ser humano passa a ser titular de direitos, ora condicionando a tutela dos direitos da personalidade ao nascimento com vida, ora garantindo os direitos do nascituro desde a concepção. Esta indefinição é, em grande parte, reflexo da ausência de consenso no que se refere ao reconhecimento do status do nascituro como pessoa humana digna, o que dificulta o desenvolvimento de um arcabouço jurídico eficaz para a regulação das inúmeras questões bioéticas que envolvem embrião e o feto. Dessa forma, o desenvolvimento deste estudo consiste em uma pesquisa de revisão bibliográfica alinhada ao método explicativo-compreensivo, tendo como objetivo compreender a problemática referente ao reconhecimento da pessoalidade, da dignidade e da personalidade jurídica do nascituro. Conclui-se que a teoria concepcionista, bem como a corrente personalista ontológica, parecem ser as que melhor se adequam ao ordenamento jurídico nacional e à análise bioética do tema, sendo o nascituro pessoa humana digna e possuidor de personalidade jurídica desde a concepção.
\end{abstract}

\section{PALAVRAS-CHAVE:}

Personalidade Jurídica, Dignidade, Nascituro, Direitos da Personalidade.

\begin{abstract}
This article seeks to analyze the problem related to the initial framework of the legal personality of the natural person. The Brazilian legal system does not clearly present an understanding regarding the moment in which the human being becomes the holder of rights, sometimes conditioning the protection of personality rights to birth with life, and sometimes guaranteeing the rights of the unborn child from conception. This lack of definition is, to a large extent, a reflection of the lack of consensus regarding the recognition of the status of the unborn child as

\footnotetext{
${ }^{1}$ Especialista em Direito Civil e Direito Processual Civil pela Faculdade Ideal - FACI/WYDEN. Graduado em Direito pela Universidade Federal do Pará - UFPA. Integrante do Grupo de Pesquisa (CNPq) "Tradição da Lei Natural". (marinhof700@gmail.com).

${ }^{2}$ Doutor em Filosofia pela Universidade do Estado do Rio de Janeiro - UERJ. Mestre em Filosofia pela Pontifícia Universidade Católica do Rio de Janeiro - PUC-RJ. Graduado em Direito pelo Centro Universitário do Estado do Pará - CESUPA. Professor nos Programas de Pós-graduação em Direito da Universidade Federal do Pará - UFPA e Centro Universitário do Estado do Pará - CESUPA. Coordenador dos grupos de pesquisa (CNPq) "Tradição da Lei Natural" e "Razão Pública, Secularização e Lei Natural". (vvspinheiro@yahoo.com.br).
} 
a dignified human person, which hinders the development of an effective legal framework for the regulation of the innumerable bioethical issues involving the embryo and the fetus. Thus, the development of this study consists of a bibliographic review research aligned with the explanatory-comprehensive method, with the objective of understanding the issue regarding the recognition of the unborn child's personality, dignity and legal personality. It is concluded that the conceptionist theory, as well as the ontological personalist current, seem to be the ones that are better suited to the national legal system and the bioethical analysis of the theme, the unborn human being being dignified and having legal personality since conception.

KEYWORDS:

Legal personality, Dignity, Unborn, Personality Rights.

\section{INTRODUÇÃO}

A problemática do marco inicial do reconhecimento da titularidade de direitos e deveres adentra em questões polêmicas que transcendem os limites das ciências jurídicas, alcançando áreas como a filosofia, a antropologia, a biologia e a medicina, pois envolve temas relacionados ao estatuto do embrião e do feto, ao início e fim da vida, ao início e fim da dignidade em relação ao ser humano, ao conceito de pessoa e aos direitos humanos. Dessa forma, apesar das discussões profundas ainda não há consenso a respeito das possíveis respostas a estas questões, por envolverem um profundo debate jurídico e bioético, umbilicalmente relacionado à efetiva concretização dos direitos fundamentais.

O artigo $2^{\circ}$ do Código Civil de 2002 traz em sua redação o marco inicial do surgimento da personalidade civil, de modo que, em sua primeira parte, estabelece que "a personalidade civil da pessoa começa do nascimento com vida"3 ${ }^{3}$. Pela leitura deste fragmento, pode-se inferir uma interpretação natalista na classificação do nascituro como sujeito de direitos, de modo que este ganharia a sua personalidade civil apenas com o nascimento.

Dando continuidade, tal artigo preceitua, no entanto, que, mesmo com a orientação de conceder a personalidade civil ao indivíduo apenas posteriormente ao nascimento com vida, "a

\footnotetext{
${ }^{3}$ BRASIL Lei ${ }^{\circ}$ 10.406, de 10 de janeiro de 2002. Institui o Código Civil. Diário Oficial [da] União, Brasília, DF, 11 jan. 2002. Disponível em: 〈http://www.planalto.gov.br/ccivil_03/leis/2002/L10406compilada.htm〉. Acesso em: 19 de fev. de 2020.
} 
lei põe a salvo, desde a concepção, os direitos do nascituro" ${ }^{4}$. Este segundo fragmento do texto normativo apresenta uma conotação fortemente concepcionista, entrando em contradição com a primeira parte do dispositivo legal.

Portanto, tem-se que o legislador, mediante a análise da redação do artigo $2^{\circ}$ do Diploma Civil vigente, manifesta um posicionamento pouco claro a respeito do surgimento da personalidade civil da pessoa natural. Além do mais, a doutrina e a jurisprudência nacional também não apresentam consenso em relação ao tema, o que enseja acalorada discussão no seio do direito constitucional no que tange à proteção da dignidade humana, do direito civil com relação ao marco inicial da personalidade civil, do direito penal em relação à tipificação do aborto e de outras práticas que visem à proteção do nascituro e do biodireito no que tange à tutela do direito fundamental à vida nos estágios iniciais do desenvolvimento humano.

Tal indefinição se mostra, em grande parte, como um reflexo da ausência de consenso acerca do reconhecimento do status do nascituro como possuidor de pessoalidade e dignidade, o que dificulta o desenvolvimento de um arcabouço jurídico eficaz para a regulação das inúmeras questões que envolvem o tratamento de embriões e fetos, tolhendo a promoção das condições institucionais necessárias para um adequado comprometimento da dignidade humana, que consiste em um dos fundamentos da República Federativa do Brasil exposto no texto constitucional no artigo $1^{\circ}$, inciso $\mathrm{III}^{5}$.

Daí a contemporânea inserção da problemática no debate das concepções filosóficas contemporâneas acerca da dignidade humana como fundamento dos Direitos Humanos, pois o estabelecimento da condição jurídica do nascituro encontra-se ligada ao estatuto do embrião e do feto, que, por sua vez, depende da compreensão do marco inicial da pessoalidade e da dignidade da pessoa natural. Além disso, o tema adentra profundamente nos campos da bioética e da biologia por requerer a necessária compreensão de fenômenos relacionados à formação e desenvolvimento do ser humano enquanto organismo biológico, indispensáveis para o entendimento do estatuto do embrião:

No debate aparentemente interminável em torno do estatuto do embrião humano, não raro a filosofia e a ciência se acham e tal forma entrelaçadas que é difícil isolar e

\footnotetext{
${ }^{4}$ Idem.

${ }^{5}$ BRASIL. Constituição Federal de 1988, Constituição da República Federativa do Brasil. Diário Oficial [da]

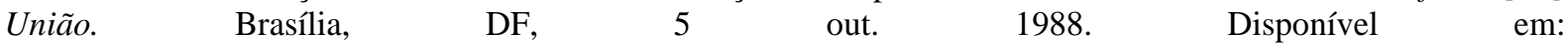
<http://www.planalto.gov.br/ccivil_03/constituicao/constituicao.htm>. Acesso em 16 de fev. de 2020.
} 
reconhecer qual seria a contribuição das ciências biológicas quanto a esse tópico. Por outro lado, as asserções filosóficas - quando não são meramente formais ou lógicas não podem excluir certa referência ao tipo de fenômenos com que estão lidando. A vida física é um fenômeno que é investigado pelas ciências empíricas, isto é, as disciplinas biológicas, e qualquer enfoque realista do estatuto dos seres vivos envolve pelo menos algum conhecimento elementar preliminar dos dados empíricos e de suas explicações possíveis.

(...) Evidentemente, a biologia nada pode dizer sobre a pessoalidade do embrião humano, uma vez que as ciências naturais não tem a pessoa como objeto formal de suas investigações. No entanto, as ciências biológicas - especialmente a genética, a bioquímica, a citologia, a biologia evolucionária e a obstetrícia - podem, em definitivo, contribuir para a discussão sobre como e quando um organismo individual humano se forma e se desenvolve: os organismos individuais, et quidem os organismos em desenvolvimento, são precisamente o material e os objetos formais da pesquisa biológica ${ }^{6}$.

Nesse sentido, as elucidações trazidas por estas ciências são fundamentais para se pensar juridicamente e filosoficamente uma série de questões relativas ao nascituro. Destaca-se assim a relevância de uma análise interdisciplinar do tema com enfoque para as ciências jurídicas, a bioética e a filosofia, pois o tema do marco inicial da personalidade jurídica carece de conhecimentos referentes ao início da vida, da dignidade e da pessoalidade ${ }^{7}$.

Analisar esta temática é de fundamental importância para a construção de um arcabouço jusfilosófico adequado para o entendimento da dignidade humana, para a tutela do ser humano em seus estágios iniciais de desenvolvimento , para a salvaguarda dos Direitos Humanos no cerne da crise dos "Novos Direitos" da quarta dimensão - dimensão da bioética e do biodireito - e para a consolidação de um entendimento amplificado no que tange ao tratamento jurídico conferido ao nascituro, objetivando garantir uma tutela com enfoque qualitativo dos direitos fundamentais.

O presente artigo busca analisar a problemática referente ao início da personalidade jurídica da pessoa natural bem como sua relação com o debate a respeito do marco inicial da pessoalidade e da dignidade humana. Assim sendo, após uma análise objetiva das teorias do início da personalidade, bem como da relação destas com as teorias de aquisição da pessoalidade e da dignidade, será realizado um juízo objetivo a respeito da problemática.

Nesse sentido, busca-se compreender os conceitos de nascituro, de personalidade jurídica e de pessoa natural; compreender as três principais teorias do início da personalidade

\footnotetext{
${ }^{6}$ SGRECCIA, Elio. Manual de bioética. Cidade do México: Diana, 1996, p. 151-152, tradução nossa.

${ }^{7}$ MALUF, Adriana Caldas do Rego Freitas Dabus. Curso de Bioética e Biodireito. $3^{\text {a }}$ ed. São Paulo: Atlas, 2015, p. 147.
} 
civil da pessoa natural, a saber, a teoria natalista, a teoria da personalidade condicional e a teoria concepcionista, bem como suas interrelações com o conceito de pessoalidade e dignidade; compreender as duas principais teorias do início da pessoalidade e da dignidade humana, ou seja, a corrente personalista ontológica e a corrente personalista funcional; compreender como o tema tem sido tratado na jurisprudência mais recente do Supremo Tribunal Federal (STF) e do Superior Tribunal de Justiça (STJ); e evidenciar que a teoria concepcionista, bem como a corrente personalista ontológica, parecem ser as que melhor se adequam ao ordenamento jurídico nacional e à análise bioética do tema, sendo o nascituro pessoa humana digna e possuidor de personalidade jurídica desde a concepção.

\section{DO CONCEITO DE NASCITURO A LUZ DO BIODIREITO E DE PERSONALIDADE JURÍDICA A LUZ DO DIREITO CIVIL}

Antes de se adentrar na discussão a respeito da problemática enfrentada, mostra-se necessário a devida conceituação de certos termos que serão recorrentes no debate. Dessa forma, será apresentado os conceitos de nascituro segundo o biodireito, de personalidade jurídica segundo o direito civil e de pessoa a luz da filosofia.

A expressão nascituro consiste etimologicamente em uma derivação do termo latino nasciturus, significando aquele que deverá nascer, conforme preleciona William Artur Pussi:

(...) comumente usado como adjetivo, particípio do futuro de nascor, também pode ser substantivo masculino, ou adjetivo conforme a sua aplicação. Nos registros dos lexicógrafos de boa fama, indica exatamente o que está por nascer. Ainda, pode ser entendido como o que há de vir ao mundo já estando concebido (concepetus), mas cujo nascimento ainda não se consumou, continuando pars ventris ou das entranhas maternas, sendo aquele que deverá nascer, nascere do étimo latino ${ }^{8}$.

Segundo a lição de Rubens Limongi França, Rodolfo Pamplona Filho e Ana Thereza Meirelles Araújo, o nascituro caracteriza-se como a pessoa que está por nascer, já concebida no ventre materno 9 . Adriana Caldas do Rego Freitas Dabus Maluf também conceitua nascituro de

\footnotetext{
${ }^{8}$ PUSSI, William Artur. Personalidade jurídica do nascituro. 2. ed. Curitiba: Juruá, 2008, p. 47.

${ }^{9}$ FARIAS, Cristiano Chaves de; ROSENVALD, Nelson. Direito Civil: Teoria Geral. 9. ed. Rio de Janeiro: Lumen Juris, 2011, p. 281.
} 
forma similar como aquele ser que ainda vai nascer, porém, já foi concebido ${ }^{10}$. Nascituro é, portanto, o ser humano concebido, porém ainda não nascido, podendo ser compreendido como uma fase do desenvolvimento humano que se estende da concepção até o nascimento.

O nascituro possui duas fases principais de desenvolvimento, a saber, o período embrionário, que se inicia com a fecundação e perdura até aproximadamente o final da oitava semana de gestação, sendo caracterizado pelo desenvolvimento das estruturas básicas de um ser humano, e o período fetal, que tem início aproximadamente com a nona semana de gestação e se estende até o nascimento, onde se observa a maturação das estruturas básicas formadas durante o período embrionário ${ }^{11}$. Com base nisto, o embrião e o feto são estágios de desenvolvimento do nascituro, que por sua vez consiste na primeira fase de desenvolvimento do ser humano.

A seu turno, a personalidade jurídica, em relação às pessoas naturais, consiste em um atributo inerente a cada ser humano, permitindo que tenham direitos e deveres de acordo com a capacidade civil. Carlos Roberto Gonçalves define personalidade jurídica da seguinte forma:

\begin{abstract}
O conceito de personalidade jurídica está umbilicalmente ligado ao de pessoa. Todo aquele que nasce com vida torna-se uma pessoa, ou seja, adquire personalidade. Esta é, portanto, qualidade ou atributo do ser humano. Pode ser definida como aptidão genérica para adquirir direitos e contrair obrigações ou deveres na ordem civil. É pressuposto para a inserção e atuação da pessoa na ordem jurídica. A personalidade é, portanto, o conceito básico da ordem jurídica, que a estende a todos os homens, consagrando-a na legislação civil e nos direitos constitucionais de vida, liberdade e igualdade. É qualidade jurídica que se revela como condição preliminar de todos os direitos e deveres ${ }^{12}$.
\end{abstract}

Portanto, o conceito de personalidade jurídica estabelece estreita relação com o de pessoa natural em sentido filosófico, sendo basilar para as ciências jurídicas, pois distingue quais são as realidades que merecem ou não a proteção jurídica como titulares de direitos e obrigações, separando-as das coisas. Nesse sentido também ensina Maria Helena Diniz:

(...) a personalidade consiste no conjunto de caracteres da própria pessoa. A personalidade não é um direito, de modo que seria errôneo afirmar que o ser humano tem direito a personalidade. A personalidade é que apoia os direitos e deveres que dela irradiam, é objeto de direito, é o primeiro bem da pessoa, que lhe pertence como primeira utilidade, para que ela possa ser o que é $e^{13}$.

\footnotetext{
${ }^{10}$ MALUF, Adriana Caldas do Rego Freitas Dabus. Curso de Bioética e Biodireito. $3^{\mathrm{a}}$ ed. São Paulo: Atlas, 2015, p. 159.

${ }^{11}$ Ibid., p. $156-157$.

12 GONÇALVES, Carlos Roberto. Direito Civil Brasileiro: Parte Geral. São Paulo: Saraiva, 2013, p. 94.

${ }^{13}$ DINIZ, Maria Helena. Curso de Direito Civil Brasileiro. $18^{\mathrm{a}}$ ed. São Paulo: Saraiva, 2002, $1^{\circ}$ Vol., p. 192.
} 
A ordem jurídica tem como seu principal objetivo a construção de um corpo normativo hábil a proteção de todos os seres que possuam personalidade. Dessa forma, qualquer ser humano, como possuidor de dignidade, faz jus ao reconhecimento, por parte do direito, desse status, que se efetiva mediante a sua classificação como sujeito de direitos Observa-se uma ligação intima entre os conceitos de personalidade jurídica, pessoalidade e dignidade, de modo que a personalidade jurídica consiste no reconhecimento conferido à um ser pessoal como titilar de direitos, sendo que este mecanismo garante a tutela de suas garantias como efetivação da dignidade.

A caracterização de um ser como pessoa para o universo jurídico viabiliza o acesso deste ao sistema de proteção estabelecido pelas normas, passando a possuir todos os direitos da personalidade, exercitando-os de acordo com a capacidade, com destaque ao direito à vida, à liberdade, ao nome, ao próprio corpo, à imagem e à honra ${ }^{14}$. Estes direitos expressam, no direito civil, a aplicação do conjunto de direitos fundamentais desenvolvidos pelos direitos humanos objetivando a salvaguarda dos bens básicos para a concretização do bem estar de todos aqueles reconhecidos como possuidores de personalidade jurídica.

Após esta brevíssima explanação dos conceitos basilares relacionados à problemática tratada, mostra-se necessário introduzir o debate a respeito das teorias da personalidade jurídica do nascituro, realizando-se a exposição objetiva destas para posteriormente ser realizado um juízo objetivo a respeito da problemática.

\section{DA ATRIbUiÇÃo DE PERSONALIDAdE JURÍdiCA AO NASCITURO COM RELAÇÃO AO DIREITO CIVIL}

Diante desse contexto de indefinição a respeito do início da existência de um ser como pessoa para o direito, três teorias principais, emergem para conferir uma resposta satisfatória a esta problemática referente ao ponto de partida da personalidade civil: a teoria natalista, a teoria da personalidade condicional e a teoria concepcionista. Todas elas buscam fundamentos

${ }^{14}$ GONÇALVES, Carlos Roberto. Direito Civil Brasileiro: Parte Geral. São Paulo: Saraiva, 2013, p. 184 
jurídicos, biológicos e filosóficos para estabelecer, de forma eficaz, em que ponto da existência um indivíduo ganha a proteção jurídica devida a cada ser humano, bem como em que amplitude esta proteção deve se manifestar.

De acordo com a teoria natalista, o nascituro não poderia ser considerado pessoa, pois o Código Civil vigente exige, para o reconhecimento da personalidade, segundo a primeira parte do artigo $2^{\circ}$, o nascimento com vida. Assim sendo, o nascituro não teria direitos, mas mera expectativa de direitos, apenas alcançando a personalidade civil de forma plena após o nascimento com vida. Conforme explica Benedita Inêz Lopes Chaves, a teoria natalista:

(...) entende que, antes do nascimento, o feto não é considerado ser humano, não tendo, portanto, personalidade jurídica, existindo apenas uma expectativa de personalidade, razão pela qual se pune o aborto provocado, resguardando a lei os direitos do nascituro, para quando do nascimento com vida. Argumentam os seguidores desta corrente que a opinião dos adeptos da teoria concepcionista é insustentável, porque o ser humano, ainda não separado do ventre materno, não tem existência própria, fazendo parte das vísceras maternas e, se o nascituro fosse considerado pessoa, além de sujeito de direitos seria também sujeito passivo de obrigações $^{15}$.

Para parte da doutrina, a teoria natalista foi acolhida pelo ordenamento jurídico pátrio, com base na hermenêutica da primeira parte do artigo $2^{\circ}$ do Código Civil vigente, pois explicita que "a personalidade civil da pessoa começa do nascimento com vida". Assim, perante o entendimento destes doutrinadores, "nascendo com vida, a criança recobre-se de personalidade, torna-se sujeito de direitos, adquirindo-os e transferindo-os. Se é natimorto, não adquire personalidade, não recebendo nem transmitindo direitos" ${ }^{\text {16 }}$. Apoiam a teoria natalista autores como Silvio Rodrigues ${ }^{17}$ e Arnoldo Wald ${ }^{18}$.

Por sua vez, a teoria da personalidade condicional sustenta o início da personalidade do nascituro a partir da concepção, com a condição de nascer com vida. Ou seja, uma vez que se verifique o nascimento com vida, a pessoa é como tal considerada desde o momento da concepção $^{19}$. Conforme Rodolfo Pamplona Filho e Ana Thereza Meirelles Araújo, a teoria da personalidade civil condicionada:

(...) sustenta a personalidade do nascituro (ou seja, desde a concepção) sob a condição de que nasça com vida. Sem o implemento da condição - nascimento com vida - não

\footnotetext{
${ }^{15}$ CHAVES, Benedita Inêz Lopes. A tutela jurídica do nascituro. São Paulo: LTr, 2000, p. 25.

${ }^{16}$ VIANA, Marco Aurélio da Silva. Curso de direito civil: parte geral. Rio de Janeiro: Forense, 2004, p. 125.

${ }^{17}$ RODRIGUES, Sílvio. Direito Civil: parte geral. 32. ed. São Paulo: Saraiva, 2002, vol. 1.

${ }^{18}$ WALD, Arnoldo. Curso de Direito Civil Brasileiro: Introdução e parte geral. 9. ed. São Paulo: Saraiva, 2002.

${ }^{19}$ PUSSI, William Artur. Personalidade jurídica do nascituro. 2. ed. Curitiba: Juruá, 2008, p. 87.
} 
haverá aquisição da personalidade. Conclusivamente, a aquisição de certos direitos (como os de caráter patrimonial) ocorreria sob a forma de condição suspensiva, ou seja, se o não nascido nascer com vida, sua personalidade retroage ao momento da concepção. Assim, o feto tem personalidade condicional, pois tem assegurada a proteção e gozo dos direitos da personalidade, mas, somente gozará dos demais direitos (os de cunho patrimonial) quando nascer com vida, ou seja, quando restar implementada a condição capaz de conferir a sua personalidade plena ${ }^{20}$.

A teoria da personalidade condicional, portanto, é aquela que advoga pelo começo da personalidade civil após o nascimento com vida, mas se diferencia da teoria natalista - ao menos em tese - porque os direitos do nascituro estariam sujeitos a uma condição suspensiva, sendo, então, meros direitos eventuais ${ }^{21}$. Condição suspensiva consiste no elemento acidental do negócio ou ato jurídico que subordina a sua eficácia a evento futuro e incerto, que nesse caso consiste no nascimento com vida. Fundamenta este raciocínio o artigo $2^{\circ}$ do atual Diploma Civil conjugado com o artigo 130 do mesmo código, que afirma ser viável ao titular do direito eventual, nos casos de condição suspensiva a prática dos atos destinados a conservá-lo.

Nesse sentido, somente lhe são assegurados à proteção e o gozo dos direitos personalíssimos, pois estes se configurariam como absolutos, incondicionais e garantidos, a todos os seres humanos, desde a concepção. Os direitos de cunho patrimonial, a seu turno, apenas serão efetivamente adquiridos quando verificada de forma eficaz a satisfação da condição suspensiva, momento em que a personalidade jurídica, segundo esta teoria, passa a existir em sua plenitude, ainda que o recém-nascido venha a falecer instantes depois. Defendem a teoria condicionalista autores como Washington de Barros Monteiro ${ }^{22}$ e Fábio Ulhoa Coelho ${ }^{23}$.

Finalmente, a teoria concepcionista sustenta que o nascituro é pessoa humana desde a concepção, tendo todos os direitos referentes à personalidade civil, resguardados pela lei, tal qual o indivíduo nascido vivo disposto na teoria natalista. Assim, preleciona Sérgio Abdalla Semião:

Segundo a escola concepcionista, a personalidade civil do homem começa a partir da concepção, ao argumento de que tendo o nascituro direitos, deve ser considerado

\footnotetext{
${ }^{20}$ FILHO, Rodolfo Pamplona; ARAÚJO, Ana Thereza Meirelles. Tutela jurídica do nascituro à luz da constituição federal. Revista Magister de Direito Civil e Processual Civil. Porto Alegre, n. 18, p. 39.

21 TARTUCE, Flávio. A situação jurídica do nascituro: uma página a ser virada no direito brasileiro. In: DELGADO, Mário Luiz; ALVES, Jones Figueirêdo. Questões controvertidas no novo código civil: parte geral. v. 6. São Paulo: Método, 2007, p. 83-104.

${ }^{22}$ MONTEIRO, Washington de Barros. Curso de Direito Civil. 37. ed. São Paulo; Saraiva, 2002, vol. 1.

${ }^{23}$ COELHO, Fábio Ulhoa. Curso de Direito Civil. São Paulo: Saraiva, 2004, vol. 1.
} 
pessoa, uma vez que só a pessoa é sujeito de direitos, ou seja, só a pessoa tem personalidade jurídica ${ }^{24}$.

Não se discute, pois, a titularidade dos direitos conferidos ao nascituro durante a gestação, faltando a este tão somente capacidade para exercê-los de forma autônoma. Esta capacidade limitada, no entanto, não lhe retira a personalidade, que decorreria naturalmente de seu status ontológico como ser humano, qualificando-o apenas como absolutamente incapaz, nos termos do artigo $3^{\circ}$ do Código Civil, que estabelece que os menores de dezesseis anos são incapazes para realizar os atos da vida civil.

Dessa forma, com relação aos direitos patrimoniais materiais, o nascimento sem vida atua, portanto, como condição resolutiva, extinguindo-os e fazendo desaparecer a sua eficácia, na qual está compreendida, inclusive, a sua transmissibilidade ${ }^{25}$.

Conclui-se que, para o concepcionismo, o embrião humano é um indivíduo em desenvolvimento, que merece o respeito e dignidade que é devido a todo ser humano a partir do momento da concepção. Esta teoria vem ganhando espaço dentro do entendimento jurídico doutrinário e jurisprudencial nas últimas décadas em virtude dos avanços científicos, principalmente com relação á embriologia e à genética, que estabelecem que o embrião, desde momentos após a fecundação já possui seu código genético único formado, código este que contém todas as informações necessárias para conduzir o desenvolvimento do ser, além de constituir sua identidade e individualidade. São adeptos da teoria concepcionista autores como Flávio Tartuce ${ }^{26}$, Maria Helena Diniz ${ }^{27}$ e Silmara Juny A. Chinellato e Almeida ${ }^{28}$.

Tal discussão a respeito do marco inicial dos direitos da personalidade aparenta possuir íntima relação com o debate sobre o momento no qual o ser humano passaria a ter dignidade e pessoalidade, pois o reconhecimento do caráter pessoal de um ser leva a ordem jurídica a reconhece sua titularidade de direitos como mecanismo de efetivação de sua dignidade. Dessa forma, as teorias da personalidade do nascituro, ao estabelecerem a dúvida se o nascituro

\footnotetext{
${ }^{24}$ SEMIÃO, Sérgio Abdalla. Os direitos do nascituro: aspectos cíveis, criminais e do biodireito. 2. ed., rev., atual. e ampl. Belo Horizonte: Del Rey, 2000, p. 35.

${ }^{25}$ CHINELATO, Silmara Juny. Estatuto jurídico do nascituro: o direito brasileiro. In: DELGADO, Mário Luiz; ALVES, Jones Figueirêdo. Questões controvertidas no novo código civil: parte geral. v. 6. São Paulo: Método, 2007, p. 43-81.

26 TARTUCE, Flávio. A situação jurídica do nascituro: uma página a ser virada no direito brasileiro. In: DELGADO, Mário Luiz; ALVES, Jones Figueiredo. Questões controvertidas no novo código civil: parte geral. v. 6. São Paulo: Método, 2007, p. 83-104.

${ }^{27}$ DINIZ, Maria Helena. Curso de Direito Civil Brasileiro. $18^{\mathrm{a}}$ ed. São Paulo: Saraiva, 2002.

${ }^{28}$ CHINELATO E ALMEIDA, Silmara J. A. Tutela Civil do Nascituro. São Paulo: Saraiva, 2000.
} 
passaria a possuir direitos a partir da concepção, ou a partir de algum momento durante a gestação, ou somente após o nascimento, ligam-se com a divergência filosófica sobre o marco inicial da pessoalidade e da dignidade humana, pela qual se discute se o ser humano ganharia este status após a concepção, em algum momento durante a gestação, após o nascimento, ou mesmo durante a infância.

Devido a isso, evidencia-se a necessidade de se expor a relação entre o debate jurídico da personalidade do nascituro com o debate filosófico a respeito da pessoalidade e da dignidade de forma a traçarmos a posteriori uma conclusão objetiva sobre o tema.

\section{A RELAÇÃO DA PROBLÉMÁTICA DO MARCO INICIAL DA PERSONALIDADE JURÍDICA COM A DO MARCO INICIAL DA PESSOALIDADE E DA DIGNIDADE}

Existem pelo menos duas interpretações distintas com relação à problemática da dignidade e da pessoalidade do nascituro: uma corrente personalista ontológica, que defende a ideia de que a dignidade consiste num atributo ontológico do ser humano, de modo que desde o início de sua existência biológica ele seria possuidor de dignidade; e outra corrente personalista funcional, que alega que a dignidade apenas pode ser atribuída a seres que possuem de forma fática características especiais como consciência, moralidade e racionalidade.

Os defensores da tese que a dignidade humana se constitui em um atributo inerente à natureza humana, tendem a se filiar à teoria concepcionista, enquanto aqueles que interpretam que a dignidade consiste em um atributo apenas conferido aos seres que possuem certas características de forma funcional tendem a se filiar a outras correntes como a natalista ou mesmo a condicionalista.

Observa-se, portanto, que a compreensão do tema em discussão necessita de elementos oriundos de várias áreas do conhecimento com destaque, para os fins deste trabalho, para o direito, especificamente o direito civil no que tange ao debate sobre a personalidade; a filosofia, com relação ao marco inicial do reconhecimento da dignidade humana e da pessoalidade; e a 
bioética, no que tange ao modo como devemos tratar o embrião e o feto considerando suas características biológicas e as consequências éticas destas.

De acordo com a tese personalista ontológica, podemos compreender dignidade como uma dimensão de debitude e exigibilidade que um ser possui em relação a si mesmo e a outros indivíduos ${ }^{29}$. Este conceito transmite a ideia de que o ser humano merece receber um tratamento adequado de si e dos outros por ser essencialmente diferente dos demais seres, possuindo habilidades diferenciadoras como racionalidade, moralidade e autonomia.

Nesse sentido, a tradição personalista atribui a pessoalidade ao ser humano com base no reconhecimento de suas capacidades de refletir sobre as coisas e sobre si, de se autodeterminar e de dar sentido às suas expressões e a sua linguagem consciente, conforme explicita Elio Sgreccia:

\begin{abstract}
A tradição personalista tem suas raízes na própria razão do homem e no coração de sua liberdade: o homem é uma pessoa porque é o único ser no qual a vida se torna capaz de "refletir" sobre si mesma, de autodeterminação; Ele é o único ser vivo que tem a capacidade de capturar e descobrir o significado das coisas e dar sentido às suas expressões e à sua linguagem consciente ${ }^{30}$.
\end{abstract}

Com isso, o ser humano, por possuir capacidades especiais, como resultado de sua natureza, mesmo não podendo realizá-las de forma funcional nos estágios iniciais de seu desenvolvimento, teria dignidade desde o início de sua existência em virtude de que estas habilidades fariam parte de sua dimensão ontológica, sendo presentes de forma potencial desde a concepção. Assim afirmam Patrik Lee e Robert P. George:

\begin{abstract}
A dignidade de uma pessoa, seja lá o que for que consiste, é aquela pela qual uma pessoa supera outros seres, especialmente outros animais, e merece respeito ou consideração de outras pessoas. Como argumentamos no capítulo 2, o que nos distingue de outros animais, o que nos torna pessoas e não coisas, é nossa capacidade de moldar nossas próprias vidas, nossa capacidade de racionalidade e livre escolha. E, como também explicamos no Capítulo 2, as capacidades de raciocinar e fazer escolhas livres são capacidades naturais básicas, possuídas por todo ser humano, mesmo aqueles que não podem exercer imediatamente essas capacidades. A dignidade, nesse sentido, deriva do tipo de entidade substancial que se é, um ser humano - e isso é dignidade no sentido mais importante. Por se basear no tipo de ser que se é, não se pode perder essa dignidade enquanto existir ${ }^{31}$.
\end{abstract}

\footnotetext{
${ }^{29}$ HERVADA, Javier. Lições Propedêuticas de Filosofia do Direito. São Paulo: Martins Fontes, 2008, p. 311.

${ }^{30}$ SGRECCIA, Elio. Manual de bioética. Cidade do México: Diana, 1996, p. 73, tradução nossa.

${ }^{31}$ PATRIK, Lee; GEORGE, Robert P. Body-Self Dualism in Conttemporary Ethics and Politics. Cambridge:

Cambridge University Press, 2008, p. 171, tradução nossa.
} 
Para esta teoria, o reconhecimento da dignidade no ser humano está intimamente relacionado ao status deste como pessoa, pois representa que lhe é devido certo tratamento diferenciado do dispensado a outros seres, objetivando o provimento de condições básicas de existência $^{32}$. Esta tutela referente aos interesses fundamentais do ser humano é promovida justamente pela atribuição de direitos, que poderia apenas ocorrer mediante o reconhecimento do ser como possuidor de personalidade, de modo que se alguém é considerado pessoa em sentido ontológico, também deve ser reconhecido como pessoa em sentido jurídico ${ }^{33}$.

Com base nessa argumentação, considerando que os direitos da personalidade se alicerçam na condição do ser humano como pessoa e no reconhecimento de sua dignidade ontológica, o marco inicial da personalidade coincidiria com o começo da vida humana, que se daria com a concepção. Com relação a isto afirmam Patrik Lee e Robert P. George:

\footnotetext{
É claro que, após a concepção, ou seja, a partir do estágio do zigoto, o desenvolvimento principal desse organismo é controlado e direcionado a partir de dentro, isto é, pelo próprio organismo multicelular. Nenhuma das mudanças que ocorrem no ser humano embrionário durante a gestação normal gera uma nova direção de crescimento. Em vez disso, todas as mudanças (por exemplo, aquelas que envolvem nutrição e meio ambiente) facilitam ou retardam o crescimento dirigido internamente desse indivíduo. Esses fatos são suficientes para mostrar que o embrião humano é um ser humano completo, embora imaturo, um membro individual da espécie homo sapiens ${ }^{34}$.
}

Dessa forma, a teoria concepcionista parece se harmonizar com os pressupostos dessa lógica de pensamento, pois permite que o nascituro, desde os momentos iniciais de sua existência, possa gozar de direitos como consequência de sua alegada dignidade ontológica e de seu reconhecimento como pessoa natural. São adeptos da tese da dignidade ontológica

\footnotetext{
${ }^{32}$ HERVADA, Javier. Lições Propedêuticas de Filosofia do Direito. São Paulo: Martins Fontes, 2008, p. 311312.

${ }^{33}$ SILVA, Reinaldo Pereira e. Introdução ao biodireito: investigações político-jurídicas sobre o estatuto da concepção humana. São Paulo: LTr, 2002, p. 221-222.

${ }^{34}$ PATRIK, Lee; GEORGE, Robert P. Body-Self Dualism in Conttemporary Ethics and Politics. Cambridge: Cambridge University Press, 2008, p. 121-122, tradução nossa.
} 
autores como Robert P. George ${ }^{35}$, Patrick Lee ${ }^{36}$, Javier Hervada ${ }^{37}$, Craig Payne ${ }^{38}$, Elio Sgreccia $^{39}$ e Robert Spaemann ${ }^{40}$.

A seu turno, de acordo com a corrente personalista funcional ou empírica, o nascituro não possuiria pessoalidade e dignidade devido ao fato deste não apresentar de forma funcional requisitos como consciência, raciocínio, desempenho de atividades automotivadas, capacidade de comunicação e autoconhecimento. Neste sentido, explica Mary Anne Warren:

\begin{abstract}
Sugiro que os traços mais centrais ao conceito de personalidade, ou humanidade, no sentido moral, sejam muito grosseiros; os seguintes: 1. consciência (de objetos e eventos externos e / ou internos ao ser), e em particular a capacidade de sentir dor; 2. raciocínio (a capacidade desenvolvida para resolver problemas novos e relativamente complexos); 3. atividade motivada (atividade relativamente independente do controle externo genético ou direto); 4. a capacidade de comunicar, por qualquer meio, mensagens de uma variedade indefinida de tipos, isto é, não apenas com um número indefinido de conteúdos possíveis, mas sobre indefinidamente muitos tópicos possíveis; 5. presença de autoconceitos e autoconsciência, individual ou racial, ou $\operatorname{ambos}^{41}$.
\end{abstract}

Por não possuir estes requisitos, não seria cabível atribuir a este o status de pessoa, nem promover um tratamento diferenciado, pois o nascituro seria comparado a qualquer outro animal não humano, de modo que embriões e fetos - e até mesmo crianças recém-nascidas não poderiam ser reconhecidos como detentores de personalidade jurídica ${ }^{42}$. Dessa forma, observa-se uma aparente relativização da garantia de direitos fundamentais conferida ao ser humano, condicionada ao atendimento de certos requisitos característicos da pessoalidade, de modo que seriam resguardados os direitos apenas dos seres humanos que ostentassem o status de pessoa. Com relação a isso assevera mais uma vez Mary Anne Warren:

Alguns seres humanos não são pessoas, e pode haver pessoas que não sejam seres humanos. Um homem ou mulher cuja consciência foi permanentemente destruída, mas que permanece viva é um ser humano que não é mais uma pessoa; seres humanos defeituosos, sem capacidade mental considerável, não são e, presumivelmente, nunca

\footnotetext{
${ }^{35}$ Idem.

${ }^{36}$ Idem.

${ }^{37}$ HERVADA, Javier. Lições Propedêuticas de Filosofia do Direito. São Paulo: Martins Fontes, 2008.

${ }^{38}$ PAYNE, Craig. Aquinas and the human person: essays in thomistc anthropology. Ottumwa: Vision Publishing, 2014.

${ }^{39}$ SGRECCIA, Elio. Manual de bioética. Cidade do México: Diana, 1996.

40 SPAEMANN, Robert. Love and the dignity of human life: on nature and natural law. Foreword by David L. Schindler. Grand Rapids, Michigan: W.B. Eerdmans, 2012a.

${ }^{41}$ WARREN, Mary Anne. On the moral and legal status of abortion. The Monist, Oxford, v. 57, n. 4, 1973, p. 55, tradução nossa.

${ }^{42}$ SINGER, Peter. Ética Practica. 2. ed. Cambridge: Cambridge University Press, 1995, p. 209-210, tradução nossa.
} 
serão pessoas; e um feto é um ser humano que ainda não é uma pessoa e que, portanto, não se pode dizer coerentemente que possua plenos direitos morais ${ }^{43}$.

Neste sentido, considerando os postulados dessa corrente, a proteção dos direitos do nascituro desde a concepção não faria sentido, já que a personalidade jurídica de um ser humano apenas seria atribuída àqueles que atendessem certos requisitos da pessoalidade, que seriam alcançados apenas após o nascimento - ou mesmo após certo período de vida extrauterina aparentemente se aproximando do que é proposto pela teoria natalista ou mesmo pelo teoria condicionalista. Sobre isso afirma Michael Tooley:

\footnotetext{
Minha abordagem será estabelecer e defender um princípio moral básico que especifique uma condição que um organismo deve satisfazer para ter um direito sério à vida. Veremos que essa condição não é satisfeita por fetos e bebês humanos e, portanto, eles não têm direito à vida. Portanto, a menos que haja outras objeções substanciais ao aborto e ao infanticídio, somos forçados a concluir que essas práticas são moralmente aceitáveis ${ }^{44}$.
}

Com isso, mesmo que um ser possua um código genético humano, isto não seria suficiente para estabelecer o reconhecimento de sua dignidade, pois não bastaria que o ser possuísse apenas potencialmente as características obrigatórias para ser pessoa, mas sim funcionalmente, afastando a tese do reconhecimento da dignidade ontológica ${ }^{45}$. São adeptos da tese personalista funcional autores como Peter Singer ${ }^{46}$, Mary Anne Warren ${ }^{47}$, Michael Tooley $^{48}$, Francis Crick ${ }^{49}$ e Judith Jarvis Thomson ${ }^{50}$.

Observa-se que, entre essas duas teorias, o principal ponto de divergência reside na compreensão do modo como as capacidades diferenciadoras do ser humano, que justificariam o reconhecimento de sua dignidade, se apresentam. Neste sentido, enquanto a teoria da dignidade ontológica entende que essas características fazem parte da essência humana, estando presentes de forma potencial desde a origem biológica do ser humano, os defensores da teoria personalista funcional consideram a necessidade daquilo que pensam ser a presença fática delas

\footnotetext{
${ }^{43}$ WARREN, Mary Anne. On the moral and legal status of abortion. The Monist, Oxford, v. 57, n. 4, 1973,p. 5657, tradução nossa.

${ }^{44}$ TOOLEY, Michael. Abortion and infanticide. Philosophy \& Public Affairs, New Jersey, v. 2, n. 1, 1972, p. 37, tradução nossa.

${ }^{45}$ WARREN, Mary Anne. On the moral and legal status of abortion. The Monist, Oxford, v. 57, n. 4, 1973, p. 54, tradução nossa.

${ }^{46}$ SINGER, Peter. Ética Practica. 2. ed. Cambridge: Cambridge University Press, 1995.

47 WARREN, Mary Anne. On the moral and legal status of abortion. The Monist, Oxford, v. 57, n. 4, 1973.

${ }^{48}$ TOOLEY, Michael. Abortion and infanticide. Nova York: Oxford University Press, 1983.

${ }^{49}$ CRICK, Francis. Astonishing hypothesis: the scientific search for the soul. Londres: Simon and Schuster, 1994.

${ }^{50}$ THOMSON, Judith Jarvis. A defense of abortion. Philosophy \& Public Affairs, v. 1, n. 1, p. 47-66, Aut. 1971.
} 
para atribuir a um ser o status de possuidor de dignidade. Essa diferença de ideias gera amplos e distintos desdobramentos, fazendo com que os defensores da dignidade ontológica normalmente advoguem por conferir um sistema de proteção amplo ao nascituro desde a concepção, enquanto que os defensores da tese personalista funcional priorizam a tutela dos interesses daqueles que supostamente possuem personalidade jurídica - os já nascidos - em face dos embriões e fetos por estes não serem pessoas.

Após estas explanações de caráter doutrinário, filosófico e bioético, cabe uma exposição jurisprudencial da problemática da personalidade jurídica do nascituro. Para isso, será analisado o entendimento do Supremo Tribunal Federal e do Superior Tribunal de Justiça exposto em decisões recentes com relação ao reconhecimento de direitos ao nascituro. Nesse sentido, a compreensão do STF e do STJ sobre o tema é emblemática por se observar um aparente conflito de interpretação.

\section{O ENTENDIMENTO JURISPRUDENCIAL DO INÍCIO DA PERSONALIDADE JURÍDICA NO SUPREMO TRIBUNAL FEDERAL E NO SUPERIOR TRIBUNAL DE JUSTIÇA}

Apesar da doutrina mais atual e de parte da legislação tender progressivamente a se filiar a teoria concepcionista, jurisprudencialmente o tema do início da personalidade jurídica ainda não encontra um entendimento pacificado. Muito pelo contrário, os tribunais oscilam em várias ocasiões entre o reconhecimento de direitos ao nascituro, como nos casos de filiação e de reparação do dano moral, e a relativização desta tutela, como nos casos da utilização em pesquisas de células tronco embrionárias, da utilização de métodos de fertilização artificial que acabam por promover o descarte de embriões excedentários e das excludentes de ilicitude do aborto.

Segundo a jurisprudência mais recente do Supremo Tribunal Federal (STF), observa-se uma indefinição com relação ao status jurídico do nascituro, ora sendo compreendido como sujeito de direitos a semelhança do que postula a teoria concepcionista, ora condicionando a 
titularidade apenas após o nascimento com vida de forma similar aos pressupostos da teoria natalista.

No julgamento do Habeas Corpus número 114901/DF de 18 de dezembro de 2018, o tribunal estabeleceu o entendimento de que a expulsão de estrangeiro não poderia se configurar caso sua companheira estivesse grávida, bastando a ocorrência da concepção para a configuração do fator impeditivo. Entretanto, apesar de expressamente afirmar que essa medida consiste numa forma de garantir a proteção dos direitos do nascituro, a decisão condiciona a titularidade destes direitos ao nascimento com vida ${ }^{51}$.

Já no Recurso Extraordinário número 1151163/CE de 30 de agosto de 2018, a proteção à saúde da gestante e do nascituro foi invocada como argumento para a postergação da realização de exame de raio $\mathrm{X}$ que deveria ser realizado em candidata gestante em concurso público $^{52}$. A proteção da saúde do nascituro também foi um dos elementos centrais invocados na discussão tecida no Recurso Extraordinário número 1170558/AM de 25 de abril de 2019, que decidiu pela estabilidade gestacional de servidora pública ocupante de cargo comissionado $^{53}$.

No Habeas Corpus número 124306/RJ de 09 de agosto de 2016, em julgamento icônico por abordar diretamente o tema da proteção jurídica do nascituro, destacou-se a necessidade de se conferir interpretação conforme a Constituição aos artigos 124 a 126 do Código Penal - que tipificam o crime de aborto - para excluir do seu âmbito de incidência a interrupção voluntária da gestação efetivada no primeiro trimestre. Foi afirmado que a criminalização do aborto, nessa hipótese, violaria diversos direitos fundamentais da mulher, bem como o princípio da proporcionalidade. Segundo interpretação dos ministros, a criminalização do aborto ate o terceiro mês de gestação constitui-se em uma medida de duvidosa adequação para proteger o bem jurídico da vida do nascituro, por não produzir impacto relevante sobre o número de abortos praticados no país, apenas impedindo que sejam feitos de modo seguro. Dessa forma, seria mais adequado que o Estado buscasse evitar a ocorrência de abortos por meios mais

\footnotetext{
51 BRASIL. Supremo Tribunal Federal: Habeas Corpus $n^{o}$ 114901/DF. Disponível em: <http://portal.stf.jus.br/processos/detalhe.asp?incidente=4288991>. Acesso em: 12 de dez. de 2019.

52 BRASIL. Supremo Tribunal Federal: Recurso Extraordinário $n^{o}$ 1151163/CE. Disponível em: <http://portal.stf.jus.br/processos/detalhe.asp?incidente=5518564>. Acesso em: 09 de dez. de 2019.

53 BRASIL. Supremo Tribunal Federal: Recurso Extraordinário no 1170558/AM. Disponível em: <http://portal.stf.jus.br/processos/detalhe.asp?incidente=5571992>. Acesso em: 15 de dez. de 2019.
} 
eficazes e menos lesivos do que a criminalização, tais como educação sexual, distribuição de contraceptivos e amparo à mulher que deseja ter o filho, mas se encontra em condições $\operatorname{adversas}^{54}$.

No Recurso Extraordinário número 998092/MA de 26 de outubro de 2016, foi estabelecido que não faz jus à indenização decorrente do seguro obrigatório DPVAT a grávida que, em razão de evento de trânsito, vem a sofrer aborto. Ressaltou-se que independentemente da corrente doutrinária adotada sobre o início da personalidade jurídica da pessoa natural, os direitos de cunho patrimonial somente são adquiridos pelas pessoas nascidas com vida, não se podendo conceber a atribuição de condição de segurado do DPVAT ao natimorto, vez que nunca adquiriu personalidade jurídica material, de forma a amparar a pretensão dos genitores à percepção de quantias a título de seguro obrigatório ${ }^{55}$.

Esta compreensão estabelecida pelo Supremo Tribunal Federal no RE 998092/MA difere da emanada pelo Superior Tribunal de Justiça no Recurso Especial número 1415727/SC de 04 de setembro 2014, que adentra diretamente ao tema do marco inicial da personalidade jurídica ao tratar de um caso similar ao Recurso Especial em tela, relacionado ao recebimento da indenização do seguro DPVAT devido à morte de nascituro em acidente automobilístico. Estabelece que a despeito da literalidade do art. $2^{\circ}$ do Código Civil - que condiciona a aquisição de personalidade jurídica ao nascimento -, o ordenamento jurídico pátrio aponta sinais de que não há essa indissolúvel vinculação entre o nascimento com vida e o conceito de pessoa, de personalidade jurídica e de titularização de direitos, como pode aparentar a leitura mais simplificada da lei.

Nesse sentido, expõe que se registram como indicativos de que o direito brasileiro confere ao nascituro a condição de pessoa, titular de direitos: a exegese sistemática dos arts. $1^{\circ}$, $2^{\circ}, 6^{\circ}$ e 45 , caput, do Código Civil; direito do nascituro de receber doação, herança e de ser curatelado segundo os artigos 542, 1.779 e 1.798 do Código Civil; a especial proteção conferida à gestante, assegurando-se atendimento pré-natal segundo o artigo $8^{\circ}$ do ECA, o qual, ao fim e ao cabo, visa a garantir o direito à vida e à saúde do nascituro; alimentos gravídicos, cuja titularidade é, na verdade, do nascituro e não da mãe com base na Lei n. 11.804/2008; no direito

\footnotetext{
54 BRASIL. Supremo Tribunal Federal: Habeas Corpus $n^{o}$ 124306/RJ. Disponível em: <http://portal.stf.jus.br/processos/detalhe.asp?incidente=4637878>. Acesso em: 15 de dez. de 2019.

55 BRASIL. Supremo Tribunal Federal: Recurso Extraordinário $n^{o}$ 998092/MA. Disponível em: <http://portal.stf.jus.br/processos/detalhe.asp?incidente=5055758>. Acesso em: 15 de dez. de 2019.
} 
penal a condição de pessoa viva do nascituro - embora não nascida - é afirmada pois o crime de aborto descrito nos artigos 124 a 127 do CP sempre esteve alocado no título referente a "crimes contra a pessoa" e especificamente no capítulo "dos crimes contra a vida" - tutela da vida humana em formação, a chamada vida intrauterina.

O STJ afirma que as teorias mais restritivas dos direitos do nascituro - natalista e da personalidade condicional - fincam raízes na ordem jurídica superada pela Constituição Federal de 1988 e pelo Código Civil de 2002, de modo que o paradigma no qual foram edificadas transitava, essencialmente, dentro da órbita dos direitos patrimoniais. Porém, atualmente isso não mais se sustenta, reconhecendo-se amplos catálogos de direitos não patrimoniais ou de bens imateriais da pessoa, como a honra, o nome, imagem, integridade moral e psíquica, entre outros.

Explicita também que mesmo que se adote qualquer das outras duas teorias restritivas, há de se reconhecer a titularidade de direitos da personalidade ao nascituro, dos quais o direito à vida é o mais importante. Garantir ao nascituro expectativas de direitos, ou mesmo direitos condicionados ao nascimento, só faz sentido se lhe for garantido também o direito de nascer, o direito à vida, que é direito pressuposto a todos os demais ${ }^{56}$.

O Superior Tribunal de Justiça também tem se posicionado em várias outras oportunidades reconhecendo direitos ao nascituro, principalmente com relação à proteção do direito à vida e do direito à saúde.

No Agravo Regimental no Agravo em Recurso Especial número 593933/SP de 19 de abril de 2018 foi estabelecido que nas ações em que se discute o direito de trabalhadora rural ou doméstica ao salário maternidade não está em discussão apenas o direito da segurada, mas, igualmente, o direito do infante nascituro, o que reforçaria a necessidade de afastamento de qualquer prazo decadencial ou prescricional que lhe retire a proteção social devida ${ }^{57}$.

No Agravo Interno no Recurso Especial número 1621945/AC de 03 de agosto de 2017, o STJ determinou multa astreinte em face da Administração Pública, haja vista o

\footnotetext{
56 BRASIL. Superior Tribunal de Justiça: Recurso Especial $n^{o}$ 1415727/SC. Disponível em: <https://ww2.stj.jus.br/processo/revista/inteiroteor/?num_registro=201401851631\&dt_publicacao=27/11/2014>. Acesso em: 07 de dez. de 2019

${ }^{57}$ BRASIL. Superior Tribunal de Justiça: Agravo Regimental no Agravo em Recurso Especial $n^{o}$ 593933/SP. Disponível <https://ww2.stj.jus.br/processo/revista/inteiroteor/?num_registro=201402437458\&dt_publicacao=07/05/2018>. Acesso em: 07 de dez. de 2019.
} 
descumprimento de ordem judicial de fornecimento de assistência à saúde com relação ao não restabelecimento do serviço de atendimento médico especializado em tempo integral no Hospital da Mulher e da Criança no município de Juruá. Fundamentou a decisão com base no direito à saúde de nascituros, recém-nascidos, grávidas e parturientes ${ }^{58}$.

No Recurso em Mandado de Segurança número 47582/MG de 19 de maio de 2015, foi estabelecido, com base na aplicação do Informativo de Jurisprudência 520 do Superior Tribunal de Justiça, que é possível a remarcação do teste de aptidão física da candidata devido ao estado gravídico, sem que importe na violação do princípio da isonomia. Este posicionamento é justificado com base não apenas na proteção constitucional dispensada à gestante, mas também ao nascituro ${ }^{59}$.

Com base nesse exame jurisprudencial, observa-se que tanto o Supremo Tribunal Federal quanto o Superior Tribunal de Justiça partilham do entendimento em vários casos de que o nascituro possui direitos a serem protegidos, com destaque ao direito à vida. Mesmo a decisão exarada no HC 124306/RJ, que interpreta a restrição penal ao aborto de forma menos ampla, considerando lícita a prática até o terceiro mês de gestação, não deixa de pugnar pela proteção à vida do nascituro questionando não seu status como pessoa, mas sim a efetividade da criminalização como mecanismo de proteção ao nascituro e aos direitos da mulher.

Observa-se, portanto, uma gradual mudança do entendimento jurisprudencial brasileiro para o reconhecimento da tese concepcionista. Entretanto, como exemplificado pela divergência presente entre os entendimentos das decisões no RE 998092/MA e no REsp 1415727/SC, ainda não há pleno consenso, de modo que o reconhecimento dos direitos do nascituro continua sendo condicionado ao evento do nascimento com vida em certos casos como em questões envolvendo direitos patrimoniais - ou se reconhecidos, encontram-se relativizados caso a manutenção da vida do nascituro possa atritar com direitos fundamentais principalmente por parte da mãe que se encontra em estado de ampla vulnerabilidade social como no caso da polêmica referente ao aborto.

\footnotetext{
${ }^{58}$ BRASIL. Superior Tribunal de Justiça: Agravo Interno no Recurso Especial $n^{\circ}$ 1621945/AC. Disponível em: $<$ https://ww2.stj.jus.br/processo/revista/inteiroteor/?num_registro=201600921929\&dt_publicacao=09/08/2017>. Acesso em: 08 de dez. de 2019.

59 BRASIL. Superior Tribunal de Justiça: Recurso em Mandado de Segurança $n^{o}$ 47582/MG. Disponível em: $<$ https://ww2.stj.jus.br/processo/revista/inteiroteor/?num_registro=201500307720\&dt_publicacao=30/06/2015>. Acesso em: 08 de dez. de 2019.
} 
Dessa forma, apesar de perder força em muitos casos, a teoria natalista continua sendo um dos fundamentos para a argumentação de que não haveria empecilhos razoáveis de ordem jurídica para a utilização de embriões em pesquisas como as que se servem de células tronco embrionárias, tema tratado no julgamento da Ação Direta de Inconstitucionalidade ${ }^{\circ}$ 3510, onde foi estabelecido a constitucionalidade da realização de pesquisas com células tronco embrionárias $^{60}$. A teoria também viabiliza a descriminalização do aborto, assunto levado ao Supremo Tribunal Federal nas Arguições de Descumprimento de Preceito Fundamental no 54 , que estabeleceu a licitude do abortamento de feto com anencefalia ${ }^{61}, \mathrm{e}^{\circ} 442$, ainda aguardando decisão, que pugna pela descriminalização do aborto até o terceiro mês de gestação ${ }^{62}$.

Entretanto, após uma análise objetiva do ordenamento jurídico, das ponderações bioéticas e filosóficas sobre o início da vida humana e do reconhecimento da pessoalidade e da dignidade, e da jurisprudência do Supremo Tribunal Federal e do Superior Tribunal de Justiça a respeito do tema, a teoria concepcionista parece ser a que melhor atenderia as peculiaridades do sistema jurídico nacional. A fundamentação para essa conclusão se da em dois âmbitos principais, um âmbito de argumentação pertencente à seara jurídica e outro à seara bioética e filosófica.

\section{A TEORIA CONCEPCIONISTA COMO ENTENDIMENTO MAIS ADEQUADO CONSIDERANDO O ORDENAMENTO JURÍDICO BRASILEIRO E AS PONDERAÇÕES BIOÉTICAS A RESPEITO}

A proteção do nascituro desde a concepção, oriunda de seu reconhecimento como possuidor de dignidade e personalidade jurídica, goza de relevante fundamentação oriunda

60 BRASIL. Supremo Tribunal Federal. Ação Direta de Inconstitucionalidade $n^{o}$ 3510. Disponível em: <http://redir.stf.jus.br/paginadorpub/paginador.jsp?docTP=AC\&docID=611723>. Acesso em: 06 de dez. de 2019. ${ }^{61}$ BRASIL. Supremo Tribunal Federal. Arguição de Descumprimento de Preceito Fundamental $n^{o}$ 54. Feto Anencéfalo. Interrupção Da Gravidez. Mulher. Liberdade Sexual e Reprodutiva. Saúde. Dignidade. Autodeterminação. Direitos Fundamentais. Crime. Inexistência. Relator: Marco Aurélio. Brasília, DF, 12 de dez. de 2019.

${ }^{62}$ BRASIL. Advocacia Geral da União: Arguição de Descumprimento de Preceito Fundamental no 442. Disponível em: <adpf442_-_federal_-_codigo_penal_-_aborto_-_legislador_positivo_-_direito_-_comparado__ausencia_direito_fundamental_ao_aborto_vf_1.pdf>. Acesso em: 12 de dez. de 2019. 
tanto do direito como de outras áreas do conhecimento. Dessa forma, pode-se apresentar as principais bases para a justificação da maior adequabilidade da teoria concepcionista frente à suas concorrentes mediante os seguintes argumentos de ordem jurídica e de ordem bioética.

\title{
6.1 Argumentos Jurídicos que respaldam a Teoria Concepcionista
}

Apesar da redação do art. $2^{\circ}$ do Código Civil considerar o nascimento com vida como marco formal do início da personalidade, o ordenamento jurídico estabelece uma série de mecanismos de proteção ao nascituro, destinando a este um sistema de garantias bastante similar ao que abrange um ser humano já nascido. Nesse sentido, é conferida ao nascituro a tutela dos direitos da personalidade de forma prática a partir do momento da concepção mesmo não se reconhecendo ainda de forma integral seu status como pessoa natural:

\begin{abstract}
Há, no Código Civil, embora a personalidade comece do nascimento com vida, um sistema de proteção ao nascituro, com as mesmas conotações da conferida a qualquer ser dotado de personalidade. Assim, é obrigatória a nomeação de um curador, se o pai falecer estando grávida a mulher, e tendo esta o poder familiar (art. 1779); pode o nascituro ser objeto de reconhecimento voluntário de filiação (art. 1609, parágrafo único); pode receber doação (art. 542) e ser contemplado em testamento (art. 1798); tem direito a uma adequada assistência pré-natal (ECA, art. $8^{\circ}$ ). O direito penal também o protege, penalizando o aborto. E a Constituição Federal assegura a todos, sem distinção, o direito à vida $\left(\operatorname{art.~} 5^{\circ}\right)^{63}$.
\end{abstract}

Esse contexto onde se garante de forma material os direitos do nascituro como se já nascido fosse, desde a concepção, entra em contradição com o entendimento firmado pela teoria natalista, pois a atribuição da titularidade de direitos a um ser logicamente impõe o reconhecimento deste como pessoa. Destaca-se que o conceito de personalidade jurídica não admite gradação da mesma forma como o conceito de capacidade. Sendo assim, considerando todo o arcabouço protetivo destinado ao nascituro, garantindo a tutela de seus interesses como se já nascido fosse, não haveria o que se falar a respeito da não existência de personalidade por parte deste, pois seria ilógico atribuir direitos a um ser sem este possuir personalidade.

A teoria concepcionista também foi recepcionada pelo Pacto de São José da Costa Rica, decorrente da Convenção Americana de Direitos Humanos de 1969, ao estatuir, em seu artigo $4^{\mathrm{o}}$, I, que "toda pessoa tem direito de que se respeite sua vida. Esse direito deve ser protegido

${ }^{63}$ GONÇALVES, Carlos Roberto. Direito Civil Brasileiro: Parte Geral. São Paulo: Saraiva, 2013, p. 105. 
pela lei e, em geral, desde o momento da concepção. Ninguém pode ser privado da vida arbitrariamente" 64 . Com isso, conforme assevera Antonio do Rêgo Monteiro Rocha, como signatário do Pacto de São José da Costa Rica, o Brasil assume a responsabilidade jurídica de garantir a proteção dos nascituros, o que só pode ser configurado mediante o reconhecimento destes como titulares de direitos ${ }^{65}$.

Dessa forma, mesmo com a não afirmação expressa do legislador com relação ao marco inicial da personalidade ocorrer na concepção, devido a falha da redação dúbia do artigo $2^{\circ}$ do Código Civil, observa-se que o ordenamento jurídico dispensa uma ampla proteção ao nascituro, reconhecendo materialmente e garantindo por meio de mecanismos variados a tutela efetiva de seus direitos fundamentais. Dessa forma, não haveria acepção entre os nascidos e os concebidos porém não nascidos, sendo os indivíduos de ambos os grupos, titulares de direitos, de modo que o nascimento seria apenas mais uma fase do desenvolvimento humano que acarretaria no máximo em uma alteração na capacidade, que é variável, mas não em seu status como pessoa, aos olhos do Direito, que é fundamentalmente invariável, afastando uma interpretação natalista:

Sem dúvida, reconhecendo o acerto da teoria concepcionista, é de se notar que a partir
da concepção já há proteção à personalidade jurídica. O nascituro já é titular de
direitos da personalidade. Com efeito, o valor da pessoa humana, que reveste todo o
ordenamento brasileiro, é estendido a todos os seres humanos, sejam nascidos ou
estando em desenvolvimento no útero materno. Perceber essa assertiva significa, em
plano principal, respeitar o ser humano em toda a sua plenitude.
Um detalhe, de qualquer sorte, parece incontroverso: a lei civil $\left(\mathrm{CC}\right.$, art. ${ }^{\circ}$ ) resguarda,
expressamente, os direitos do nascituro, servindo para afastar peremptoriamente a tese
natalista, por pregar que somente seria possível reconhecer direitos do nascituro
depois de nascer vivo ${ }^{66}$.

A teoria natalista sugere a constatação lógica de que, se o nascituro não possui personalidade, não seria pessoa em sentido jurídico, sendo classificado como reles coisa segundo a dualidade inerente ao direito civil de classificar os seres e objetos como pessoas ou coisas. Portanto, vai de encontro à tendência pós-moderna no Direito Civil de conferir proteção

\footnotetext{
${ }^{64}$ BRASIL. Procuradoria Geral do Estado de São Paulo: Convenção Americana de Direitos Humanos. Disponível em: <http://www.pge.sp.gov.br/centrodeestudos/bibliotecavirtual/instrumentos/sanjose.htm>. Acesso em $10 \mathrm{de}$ dez. de 2019.

${ }^{65}$ MONTEIRO, Antonio do Rêgo Rocha. O nascituro e sua personalidade civil à luz dos arts. $2^{\circ}$ do $\mathrm{CC}$ e $5^{\circ}$, $\S 3^{\circ}$, da CF/1988. In: ABREU, Pedro Manoel; OLIVEIRA, Pedro Miranda de (Coord.). Direito e processo: estudos em homenagem ao Desembargador Norberto Ungaretti. Florianópolis: Conceito Editorial, 2007, p. 58.

${ }^{66}$ FARIAS, Cristiano Chaves de; ROSENVALD, Nelson. Direito Civil: Teoria Geral. 9. ed. Rio de Janeiro: Lumen Juris, 2011, p. 283.
} 
jurídica ao nascituro, subentendendo sua condição como possuidor de personalidade, pois não pode haver titularidade de direitos sem personalidade.

Do ponto de vista prático, a teoria natalista nega ao nascituro mesmo os seus direitos fundamentais relacionados à sua personalidade, como o direito à vida, à investigação de paternidade, aos alimentos, ao nome e até à imagem. Com essa negativa, a teoria natalista esbarra em dispositivos do Código Civil que consagram direitos àquele que foi concebido e não nasceu, sendo esta negativa de direitos um argumento forte para sustentar a superação desta corrente doutrinária.

Crítica similar pode ser lançada contra a teoria condicionalista, pois apesar desta conceder direitos ao nascituro, os deixa condicionados ao termo da consumação do nascimento com vida, reconhecendo a existência de personalidade apenas posteriormente a este momento, recaindo no mesmo erro atribuído à teoria natalista de conferir a titularidade de direitos a um ser sem reconhecer sua personalidade. Além disso, a teoria condicionalista se apegaria a questões patrimoniais, não respondendo ao apelo das correntes mais atuais do Direito Civil de garantir a proteção de direitos pessoais ou da personalidade em favor do nascituro, de forma progressivamente ampliada.

Com isso, considerando o ordenamento jurídico nacional, bem como a interpretação doutrinária e jurisprudencial do tema, evidencia-se que a teoria concepcionista parece mostrarse como a mais adequada com relação ao estabelecimento do marco inicial da personalidade civil da pessoa natural, baseado em toda a construção normativa existente que confere direitos e garantias ao nascituro desde a concepção. Apesar da relativização de certos direitos e do condicionamento de outros ao nascimento com vida - como os direitos patrimoniais -, na grande maioria dos casos observa-se a tutela do direito a vida e dos direitos da personalidade do nascituro como se já nascido fosse.

\subsection{Argumentos Bioéticos que respaldam a Teoria Concepcionista}

Os avanços promovidos pelas pesquisas científicas, principalmente com relação à embriologia e à genética, também têm influenciado progressivamente o reconhecimento da concepção como marco inicial da vida humana e da personalidade como consequência 
principalmente de acordo com interpretações como a realizadas pelo personalismo ontológico. O embrião, desde a fecundação, já possui seu código genético único estruturado, distinto do código genético dos pais, contendo todas as informações necessárias para conduzir o desenvolvimento do ser. Com isso, o código genético recém formado do nascituro é o elemento central que determinará o desenvolvimento de todas as suas características únicas, estabelecendo assim sua individualidade, bem como sua pertença a espécie humana.

As características fundamentais para que um ser possa ser considerado vivo seriam a existência de um sistema dinâmico e autocontrolado - homeostase -, resposta à estímulos de diferentes natureza e origem - excitabilidade -, auto reprodutibilidade, herança de caracteres e a tendência evolutiva ${ }^{67}$. Observa-se que após a concepção, o embrião já possui todas estas características podendo ser considerado como um organismo vivo em estágio inicial de desenvolvimento, diferenciado do organismo paterno ou materno. Este fator aliado à noção de que o embrião já possuiria um patrimônio genético único e pertencente à espécie humana, levam a conclusão de que o início da vida e, por consequência, da personalidade, se daria com a concepção:

\begin{abstract}
A ontogenia humana, isto é, o aparecimento de um novo ser humano, ocorre com a fusão dos gametas feminino e masculino, dando origem ao zigoto, com um código genético distinto do óvulo e do espermatozoide. A fetologia e as modernas técnicas de medicina comprovam que a vida inicia-se no ato da concepção, ou seja, da fecundação do óvulo pelo espermatozoide, dentro ou fora do útero. A partir daí tudo é transformação morfológico-temporal, que passará pelo nascimento e alcançará a morte, sem que haja qualquer alteração do código genético, que é singular, tornando a vida humana irrepetível e, com isso, cada ser humano único ${ }^{68}$.
\end{abstract}

Considerando este raciocínio bioético, a tese defendida pelos concepcionistas mostra-se mais adequada, por conceder a personalidade civil aos indivíduos desde a concepção, pois este seria o marco inicial da existência humana, onde o mesmo apresenta todas as características necessárias para ser identificado como indivíduo com vida orgânica e biológica própria. A teoria concepcionista também aparenta ser mais congruente com a construção de um sistema de proteção integral da dignidade humana que garanta de forma mais completa a tutela jurídica dos direitos fundamentais do ser humano desde os momentos mais iniciais de sua existência biológica.

\footnotetext{
${ }^{67}$ CORREA, Juan de Dios; SGRECCIA, Elio. Identidade e estatuto do embrião humano: Atas da Terceira Assembléia da Pontifícia Academia para a Vida. Bauru: Editora da Universidade do Sagrado Coração, 2007, p. 155.

${ }^{68}$ DINIZ, Maria Helena. O Estado Atual do Biodireito. 9. ed. São Paulo, Saraiva, 2014, p. 52.
} 
A dignidade da pessoa humana funciona, portanto, como um mecanismo que determina a necessidade de se promoverem condições mínimas de tratamento fundamentais ao bem estar, em respeito ao atendimento às necessidades básicas do indivíduo considerado digno:

\begin{abstract}
Junto com a ideia de eminência ou excelência, a dignidade implica a de mérito ou merecimento e de comportamento adequado. Quando dizemos que alguém é digno, de modo implícito estamos dizendo que merece um tratamento adequado - p. ex., respeito e honra - e que há comportamentos adequados e inadequados a ele. E assim "tratamento indigno" ou "comportamento indigno" são expressões que se referem à adequação ou inadequação ao que merece o ser para o qual usamos esses termos. De acordo com isso, fala-se de dignidade da pessoa humana, porque com isso expressa-se uma ideia comum: a pessoa humana merece um tratamento adequado ao seu estatuto ontológico, e há comportamentos conformes (dignos) e desconformes (indignos) a esse estatuto ontológico. Isso não pode significar outra coisa a não ser que a natureza humana é constituída em regra de comportamento - próprio e alheio e em título do devido ao homem (direitos e deveres inerentes à dignidade da pessoa humana). O conforme a natureza é digno; o desconforme é indigno. Isso nos indica que a pessoa contém em si uma regra objetiva dos próprios atos (ética ou moral) e dos atos alheios em relação a ela (direito natural ou não-positivo). Desse modo, a dignidade da pessoa humana, constituída em regra de comportamento, regra ou norma que tem seu fundamento e origem na natureza humana e por isso é objetiva ${ }^{69}$.
\end{abstract}

O reconhecimento da dignidade no ser humano está intimamente relacionado ao status deste como pessoa, pois representa que lhe é devido certo tratamento diferenciado do dispensado a outros seres, objetivando o provimento de condições básicas de existência. Esta tutela referente aos interesses fundamentais do ser humano é promovida justamente pela atribuição de direitos, atribuição esta que só pode ocorrer mediante o reconhecimento do ser como possuidor de personalidade, de modo que se alguém é considerado pessoa em sentido ontológico, também deve ser reconhecido como pessoa em sentido jurídico, como forma de se respeitar a dignidade humana de forma integral. Considerando que os direitos da personalidade se alicerçam na condição do ser humano como pessoa e no reconhecimento de sua dignidade, o marco inicial da personalidade coincidiria com o marco inicial da vida humana que se daria com a concepção.

Dessa forma, a fundamentação trazida pela tese personalista ontológica parece possuir o mérito de estabelecer uma compreensão segura que garanta o reconhecimento da pessoalidade e da dignidade do ser humano, a partir do surgimento da primeira célula do indivíduo. $O$ fato desta célula possuir um código genético único reconhecível como de um membro da espécie humana e apresentar, a partir da concepção, características indispensáveis para ser considerado

${ }^{69}$ HERVADA, Javier. Lições Propedêuticas de Filosofia do Direito. São Paulo: Martins Fontes, 2008, p. 311-312. 
um ser autônomo e individual, oferece razões para se considerar este marco como o mais adequado para o surgimento da vida biológica do ser humano.

O estabelecimento da concepção como o momento inaugural tanto da vida biológica como da pessoalidade e da dignidade do ser consiste em um marco aparentemente seguro, pois se observa uma divisão mais clara entre um estágio anterior - marcado pela existência de duas células haploides oriundas do organismo masculino e feminino, possuidoras de um código genético resultado de um processo de divisão celular meiótico - e um outro estágio posterior no qual surge uma única célula com código genético inédito e plenamente capaz de se desenvolver gerando um indivíduo adulto se atendidas suas necessidades básicas. $\mathrm{O}$ estabelecimento do marco inicial em alguma fase anterior à concepção parece ser pouco razoável no sentido de que qualquer evento biológico prévio consistiria em um processo relacionado aos gametas, que são partes de outros organismos independentes. A seu turno, qualquer evento biológico posterior à concepção consistiria em um processo relacionado ao desenvolvimento do novo ser, que já goza de todas as características humanas de forma fática ou potencial.

A atribuição de pessoalidade desde esse momento também aparenta ser razoável, pois impede a existência de seres humanos impessoais que não possuiriam dignidade, o que poderia gerar precedentes no sentido da "coisificação" destes seres, afastando assim, o risco da eugenia. Nesse sentido a tese personalista ontológica consegue justificar um sistema de proteção que impeça a violação de direitos do nascituro com fundamento neste reconhecimento, atuando em prol da proteção da vida humana de forma prudente.

A crítica feita contra o modelo personalista funcional consiste justamente na dúvida com relação à qual seria o momento em que o ser humano, apesar de já ser considerado biologicamente vivo, passaria a possuir pessoalidade. Se for considerado para a obtenção da pessoalidade a presença funcional de características tipicamente humanas como raciocínio, autodeterminação, interação social, entre outras, mesmo crianças de pouca idade poderiam não atender de forma plena estes requisitos, o que incorreria numa perda ou relativização lógica perigosa do reconhecimento de seus direitos, bem como de seu status pessoal. Indivíduos possuidores de deficiências físicas ou mentais que atingissem de forma funcional suas capacidades de interação com o ambiente, de socialização e de raciocínio, reduzindo-as, também poderiam ter sua dignidade relativizada ou retirada com base nesses pressupostos. 
Com isso, a teoria concepcionista munida de fundamentação jurídica extraída de uma interpretação sistemática do ordenamento jurídico, aliada com o substrato bioético e filosófico oriundo da tese personalista ontológica parece ser razoável, pois permite que o nascituro, desde os momentos iniciais de sua existência, possa gozar de direitos que são corolários de sua dignidade e de seu reconhecimento como pessoa natural.

\section{CONSIDERAÇÕES FINAIS}

O ordenamento jurídico nacional, influenciado pelos direitos humanos, estabelece um conjunto amplo de mecanismos de proteção aos grupos possuidores de vulnerabilidades como idosos, mulheres, pessoas com deficiência, crianças, entre outros. Este tratamento se baseia na busca pela promoção de igualdade material a indivíduos que, por condições diversas, não possuem acesso aos mesmos recursos e meios oferecidos pela sociedade para o seu pleno desenvolvimento e bem estar. Dessa forma, o direito acaba por oferecer um tratamento diferenciado a estas pessoas objetivando a compensação de suas vulnerabilidades e a salvaguarda efetiva de seus direitos de forma equitativa.

Nesse sentido, os indivíduos concebidos, porém não nascidos, por estarem à mercê da vontade dos já nascidos, possuem um amplo grau de vulnerabilidade devido à sua fragilidade tanto em sentido biológico quanto em sentido social. Considerando a tutela conferida pelo ordenamento jurídico pátrio aos grupos vulneráveis, observa-se que a proteção jurídica do nascituro de forma ampla e diferenciada também deve ser estabelecida e formalizada em resposta ao alto grau de vulnerabilidade em que estes indivíduos se encontram. Portanto, para que o nascituro possa ser protegido de forma adequada, urge o reconhecimento de sua titularidade de direitos desde a concepção como marco biológico referente ao início da existência de um ser humano possuidor de dignidade.

É possível concluir que a teoria concepcionista parece ser a que melhor se adequa tanto a uma análise sistêmica do ordenamento jurídico nacional, quanto a uma interpretação bioética personalista ontológica. Nesse sentido, a teoria viabiliza a construção de um arcabouço jurídico sólido para a tutela dos direitos do ser humano, desde sua origem biológica, reduzindo as 
brechas possíveis para a violação de garantias tanto para o nascituro como também para outros grupos que por algum motivo venham a ter suas capacidades mentais e físicas reduzidas.

Questões relativas aos conflitos existentes entre os direitos do nascituro e os direitos da mulher como no caso do aborto, os possíveis ganhos que podem ser obtidos com pesquisas envolvendo células tronco embrionárias, as possibilidades para a fertilidade humana advindas pelas técnicas de reprodução assistida que incorrem no descarte de embriões, as modernas técnicas de engenharia genética que prometem a manipulação das características dos nascituros, a clonagem, entre outras, devem ser analisadas tendo em vista a proteção da vida como garantia básica. Não se fala necessariamente na vida como direito absoluto, pois até mesmo este pode admitir relativização em certos casos, entretanto faz parte da responsabilidade pessoal e coletiva tanto da sociedade quanto da comunidade científica o primado da proteção à vida como fonte das infinitas possibilidades que são conferidas ao ser humano.

\section{REFERÊNCIAS BIBLIOGRÁFICAS}

BRASIL. Advocacia Geral da União: Arguição de Descumprimento de Preceito Fundamental $n^{\circ}$ 442. Disponível em: <adpf442_-_federal_-_codigo_penal_-_aborto_-_legislador_positivo__direito_-_comparado_-_ausencia_direito_fundamental_ao_aborto_vf_1.pdf $>$. Acesso em: 12 de dez. de 2019.

. Constituição Federal de 1988, Constituição da República Federativa do Brasil. Diário Oficial [da] União. Brasília, DF, 5 out. 1988. Disponível em: <http://www.planalto.gov.br/ccivil_03/constituicao/constituicao.htm>. Acesso em $16 \mathrm{de}$ fev. de 2020.

\section{União.}

Lei $\mathrm{n}^{\circ}$ 10.406, de 10 de janeiro de 2002. Institui o Código Civil. Diário Oficial [da] <http://www.planalto.gov.br/ccivil 03/leis/2002/L10406compilada.htm>. Acesso em: 19 de fev. de 2020.

\footnotetext{
Procuradoria Geral do Estado de São Paulo: Convenção Americana de Direitos

Humanos. Disponível em: <http://www.pge.sp.gov.br/centrodeestudos/bibliotecavirtual/instrumentos/sanjose.htm>. Acesso em 10 de dez. de 2019.
} 
<https://ww2.stj.jus.br/processo/revista/inteiroteor/?num_registro=201600921929\&dt_publica cao=09/08/2017>. Acesso em: 08 de dez. de 2019.

Superior Tribunal de Justiça: Agravo Regimental no Agravo em Recurso Especial no 593933/SP. Disponível em: $<$ https://ww2.stj.jus.br/processo/revista/inteiroteor/?num_registro=201402437458\&dt_publica cao=07/05/2018>. Acesso em: 07 de dez. de 2019 .

Disponível

Superior Tribunal de Justiça: Recurso em Mandado de Segurança $n^{\circ}$ 47582/MG. <https://ww2.stj.jus.br/processo/revista/inteiroteor/?num_registro=201500307720\&dt_publica cao=30/06/2015>. Acesso em: 08 de dez. de 2019 .

Superior Tribunal de Justiça: Recurso Especial $n^{o}$ 1415727/SC. Disponível em: $\langle$ https://ww2.stj.jus.br/processo/revista/inteiroteor/?num_registro=201401851631\&dt_publica cao=27/11/2014>. Acesso em: 07 de dez. de 2019

Disponível

Supremo Tribunal Federal. Ação Direta de Inconstitucionalidade $n^{o} 3510$. $<$ http://redir.stf.jus.br/paginadorpub/paginador.jsp?docTP=AC\&docID=611723>. Acesso em: 06 de dez. de 2019.

Supremo Tribunal Federal. Arguição de Descumprimento de Preceito Fundamental $n^{o}$ 54. Feto Anencéfalo. Interrupção Da Gravidez. Mulher. Liberdade Sexual e Reprodutiva. Saúde. Dignidade. Autodeterminação. Direitos Fundamentais. Crime. Inexistência. Relator: Marco Aurélio. Brasília, DF, 12 de dez. de 2019.

- Supremo Tribunal Federal: Habeas Corpus $n^{o}$ 114901/DF. Disponível em: $<$ http://portal.stf.jus.br/processos/detalhe.asp?incidente=4288991>. Acesso em: $12 \mathrm{de} \mathrm{dez}$. de 2019.

Supremo Tribunal Federal: Habeas Corpus $n^{o}$ 124306/RJ. Disponível em: $<\mathrm{http}: / /$ portal.stf.jus.br/processos/detalhe.asp?incidente=4637878>. Acesso em: $15 \mathrm{de}$ dez. de 2019.

. Supremo Tribunal Federal: Recurso Extraordinário no 998092/MA. Disponível em: <http://portal.stf.jus.br/processos/detalhe.asp?incidente=5055758>. Acesso em: $15 \mathrm{de} \mathrm{dez}$. de 2019.

Supremo Tribunal Federal: Recurso Extraordinário no 1151163/CE. Disponível em: $<$ http://portal.stf.jus.br/processos/detalhe.asp?incidente=5518564>. Acesso em: 09 de dez. de 2019.

Supremo Tribunal Federal: Recurso Extraordinário $n^{\circ}$ 1170558/AM. Disponível em: <http://portal.stf.jus.br/processos/detalhe.asp?incidente=5571992>. Acesso em: 15 de dez. de 2019.

CHAVES, Benedita Inêz Lopes. A tutela jurídica do nascituro. São Paulo: LTr, 2000. 
CHINELATO E ALMEIDA, Silmara J. A. Estatuto jurídico do nascituro: o direito brasileiro. In: DELGADO, Mário Luiz; ALVES, Jones Figueirêdo. Questões controvertidas no novo código civil: parte geral. v. 6. São Paulo: Método, 2007.

Tutela Civil do Nascituro. São Paulo: Saraiva, 2000.

COELHO, Fábio Ulhoa. Curso de Direito Civil. São Paulo: Saraiva, 2004, vol. 1.

CORREA, Juan de Dios; SGRECCIA, Elio. Identidade e estatuto do embrião humano: Atas da Terceira Assembléia da Pontifícia Academia para a Vida. Bauru: Editora da Universidade do Sagrado Coração, 2007.

CRICK, Francis. Astonishing hypothesis: the scientific search for the soul. Londres: Simon and Schuster, 1994.

DINIZ, Maria Helena. Curso de Direito Civil Brasileiro. $18^{\mathrm{a}}$ ed. São Paulo: Saraiva, 2002, $1^{\circ}$ Vol.

. O Estado Atual do Biodireito. 9. ed. São Paulo, Saraiva, 2014.

FARIAS, Cristiano Chaves de; ROSENVALD, Nelson. Direito Civil: Teoria Geral. 9. ed. Rio de Janeiro: Lumen Juris, 2011.

FILHO, Rodolfo Pamplona; ARAÚJO, Ana Thereza Meirelles. Tutela jurídica do nascituro à luz da constituição federal. Revista Magister de Direito Civil e Processual Civil. Porto Alegre, n. 18.

GONÇALVES, Carlos Roberto. Direito Civil Brasileiro: Parte Geral. São Paulo: Saraiva, 2013.

HERVADA, Javier. Lições Propedêuticas de Filosofia do Direito. São Paulo: Martins Fontes, 2008.

MALUF, Adriana Caldas do Rego Freitas Dabus. Curso de Bioética e Biodireito. $3^{\text {a }}$ ed. São Paulo: Atlas, 2015.

MONTEIRO, Antonio do Rêgo Rocha. O nascituro e sua personalidade civil à luz dos arts. $2^{\circ}$ do $\mathrm{CC}$ e $5^{\circ}$, $\S 3^{\circ}$, da CF/1988. In: ABREU, Pedro Manoel; OLIVEIRA, Pedro Miranda de (Coord.). Direito e processo: estudos em homenagem ao Desembargador Norberto Ungaretti. Florianópolis: Conceito Editorial, 2007.

MONTEIRO, Washington de Barros. Curso de Direito Civil. 37. ed. São Paulo; Saraiva, 2002, vol. 1.

PATRIK, Lee; GEORGE, Robert P. Body-Self Dualism in Conttemporary Ethics and Politics. Cambridge: Cambridge University Press, 2008.

PAYNE, Craig. Aquinas and the human person: essays in thomistc anthropology. Ottumwa: Vision Publishing, 2014. 
PUSSI, William Artur. Personalidade jurídica do nascituro. 2. ed. Curitiba: Juruá, 2008.

RODRIGUES, Sílvio. Direito Civil: parte geral. 32. ed. São Paulo: Saraiva, 2002, vol. 1.

SEMIÃO, Sérgio Abdalla. Os direitos do nascituro: aspectos cíveis, criminais e do biodireito. 2. ed., rev., atual. e ampl. Belo Horizonte: Del Rey, 2000, p. 35.

SILVA, Reinaldo Pereira e. Introdução ao biodireito: investigações político-jurídicas sobre o estatuto da concepção humana. São Paulo: LTr, 2002.

SINGER, Peter. Ética Practica. 2. ed. Cambridge: Cambridge University Press, 1995.

SPAEMANN, Robert. Love and the dignity of human life: on nature and natural law. Foreword by David L. Schindler. Grand Rapids, Michigan: W.B. Eerdmans, 2012a.

SARLET, Ingo Wolfgang. Dignidade da pessoa humana e direitos fundamentai na Constituição Federal de 1988. 9. ed. rev. atual, Porto Alegre: Livraria do Advogado, 2011.

SGRECCIA, Elio. Manual de bioética. Cidade do México: Diana, 1996.

TARTUCE, Flávio. A situação jurídica do nascituro: uma página a ser virada no direito brasileiro. In: DELGADO, Mário Luiz; ALVES, Jones Figueirêdo. Questões controvertidas no novo código civil: parte geral. v. 6. São Paulo: Método, 2007.

THOMSON, Judith Jarvis. A defense of abortion. Philosophy \& Public Affairs, v. 1, n. 1, Aut. 1971

TOOLEY, Michael. Abortion and infanticide. Nova York: Oxford University Press, 1983.

VIANA, Marco Aurélio da Silva. Curso de direito civil: parte geral. Rio de Janeiro: Forense, 2004.

WALD, Arnoldo. Curso de Direito Civil Brasileiro: Introdução e parte geral. 9. ed. São Paulo: Saraiva, 2002.

WARREN, Mary Anne. On the moral and legal status of abortion. The Monist, Oxford, v. 57, n. 4, 1973.

Data de Submissão: 04/03/2020

Data de Aceite: 12/04/2020 